\title{
REVIEW
}

\section{TERTIARY EDUCATION IN THE PHYSICAL SCIENCES}

\author{
C. DAHANAYAKE ${ }^{1 *}$ and H.D. GUNAWARDHANA ${ }^{2}$ \\ 1 410/120, Bauddhaloka Mawatha, Colombo 07 \\ 2 Department of Chemistry, University of Colombo, Colombo 3
}

(Received: 02 February 1998; accepted: 02 October 1998)

\begin{abstract}
University education started in 1921 with the establishment of the Ceylon University College located adjacent to Royal College, Colombo. This became the University of Ceylon in 1942. Since then there has been a rapid increase in the number of universities. At present there are twelve including the Open University. Teaching of physical sciences has generally kept pace with the needs of the country. Course content has changed and methods of teaching and evaluation have also undergone change. More emphasis on technical education and for research relevant to the development needs of the country is needed. There is also a need to provide more incentives in all research institutions for research, oriented towards the award of postgraduate degrees.
\end{abstract}

Key words: Education, higher, physical science, tertiary education, universities

\subsection{DEVELOPMENTS IN TERTLARY EDUCATION}

Tertiary education in Sri Lanka at present is conducted mainly in Universities and other higher educational institutions such as technical colleges and academic professional colleges. Most of them are run by the government while some are privately owned.

\subsection{Universities}

In the nineteenth century and the first four decades of the twentieth, there was no university in Sri Lanka (then Ceylon). A few colleges, particularly Royal College, prepared students to sit examinations conducted by foreign universities such as Calcutta University and later University of London. Ceylon Medical College, established in 1870 made a very satisfactory contribution to the production of medical personnel. However even in this field, the well-to-do sent their children abroad. Agitation for the establishment of a university in Sri Lanka started in the late nineteenth century and continued at the beginning of this century, spearheaded by such stalwarts as Ananda Coomaraswamy and Sir Ponnambalam Arunachalam. The government accepted in 1912, the recommendation of the Legislative Council to establish a university. However, due to the outbreak of the first world war and the low priority given to the issue, the Ceylon University College was established only in 1921, in Colombo. 
As the name implied, this College prepared students to sit extemal examinations, conducted by an outside university, the University of London. However, the University College was considered only as a preliminary step in the establishment of a full-fledged university. A draft constitution for a unitary and residential university had been drawn up and revised. There was a long drawn-out battle of sites, one group supporting Colombo and the other a site in Kandy. The latter finally won. The University of Ceylon was established on I July 1942 with Dr (later Sir) Ivor Jennings as Vice Chancellor. Plans were drawn for the buildings at Peradeniya but the second World War was the main cause of delay in establishing the university there. Thus the university remained in Colombo. The Arts Faculty was shifted to Peradeniya in 1952. The Ceylon Medical College, which became the Faculty of Medicine of the University of Ceylon on 1942, and the Faculties of Science and Engineering remained in Colombo. Faculties of Law and Agriculture and Veterinary Science had been shifted in 1949 to Peradeniya. By the time Sir Ivor Jennings left the university in 1955, the university had been very firmly established with its autonomy preserved.

With increasing numbers seeking admission to the university, the need for expansion of university facilities became unavoidable. Also there was a demand for teaching to be conducted in the local languages-Sinhalese and Tamil. Two universities were created in 1958. They were the Vidyodaya University of Ceylon and the Vidyalankara University of Ceylon which were subsequently named as Sri Jayewardenepura and Kelaniya University respectively.

With the increased demand for science based education, it was decided to retain the Faculty of Science in Colombo and start a new one at Peradeniya in 1961. The Medical faculty was similarly duplicated. 'The Engineering Faculty was shifted to new premises at Peradeniya. With the Arts Faculty intake at Peradeniya increasing to 1600 in 1961, the full residential requirement was abandoned, with about half the intake resident outside and attending lectures. In 1963 a second unit of the Arts and Oriental Faculties was re-established in Colombo. From 1960 to 1965 Arts students intake had quadrupled. The Arts Faculty in Colombo was expanded by acquiring the Colombo Race Course. 3000 were admitted without proper facilities. This led to a series of strikes during the following years.

A major change in the university system was the enactment of Higher Education Act No. 20 of 1966. It established a National Council of Higher Education (NCHE) with wide powers over the Universities. The Vice Chancellor of a University was appointed by the Minister of Education from three names submitted by NCHE. During the period of office of the NCHE (1966-72) two new universities were established. Colombo Campus of the University of Ceylon as University of Colombo, and a College of Advanced Technology at Katubedda, which later became the University of Moratuwa. 
After the insurgency of April 1971, the Universities came under direct control of the Ministry of Education. The University of Ceylon Act, No. 1 of 1972 created one university by making all the then existing universities its campuses. The single university had its headquarters at the Senate House in Colombo. This re-organization was expected to be done during a period of transition of two years, but was extended by the Minister successively till 1st January 1979. Throughout this period from 1971 to the end of 1978 the Campuses were governed under transitional provisions. The Jaffna Campus was started in 1974.

In 1977, a Ministry of Higher Education was created. A new University Act No. 16 of 1978 established a University Grants Commission and adequately restored the autonomy of the universities which were recreated from the campuses of the single university established by the University of Ceylon Act No. 1 of 1972.

In addition to the Universities of Colombo, Peradeniya, Sri Jayewardenepura, Kelaniya, Moratuwa and Jaffna, two more regional universities were established in the eighties: the Eastern University near Batticaloa which started as a University College in 1981 and University of Ruhuna at Matara in the South from the University College founded in 1978. An Open Unjversity conducting courses mainly by mail throughout the country was started in 1980. The Rajarata University at Mihintale and the Sabaragamuwa University at Belihuloya were established in November 1995. The South Eastern University was created. in 1996 based at Addalaichchenai. At present there are eleven regionally distributed universities and one Open University in Sri Lanka.

All universities excluding the University of Moratuwa and including the Open University have Faculties of Science (or applied science) and conduct undergraduate courses leading to the degree of B. Sc. Nearly all of these have departments of chemistry, mathematics, physics, botany and zoology. Colombo in addition has a department of statistics and computer science. It also has an. Institute of Computer Technology and a Radio Isotope Centre. It conducts post-graduate studies leading up to M. Sc., M. Phil and Ph.D.

Among the Universities with physical science based faculties, Peradeniya has in addition to that of science, a Faculty of Engineering also. This faculty also has a department of computer science. The Faculty of Science has a department. of geology and a recently established department of molecular biology. These are now under the newly established Postgraduate Institute of Science. It also conducts postgraduate studies up to $\mathrm{M}$. Phil, Ph.D. in all the major science disciplines.

Sri Jayewardenepura University has a Faculty of Applied Seiences. It conducts studies leading upto the Ph.D. University of Kelaniya, has in its science faculty in addition to the usual basic science departments, a department of 
microbiology and a department of industrial management. The department of mathematics conducts, in addition to pure and applied mathematics, a degree course in statistics and computer science. The faculty conducts studies in most of the science disciplines up to Ph.D. level.

The University of Moratuwa is basically engineering oriented. The Faculty of Engineering has also a department of textile and clothing technology. The university has a separate Faculty of Architecture devoted to architecture, building economics and town and country planning. The university conducts studies up to M. Sc. and $\mathrm{Ph} . \mathrm{D}$. in many of the relevant disciplines.

The Faculty of Science, University of Jaffna has in adclition to the normal. departments, a department of computer science. Studies in most disciplines are conducted up to the Ph.D. level.

The University of Ruhuna, Faculty of Science has a separate department of fisheries biology. The faculty conducts studies up to the Ph.D.

The Rajarata University has a Faculty of applied sciences, at two campuses (Wayamba and Polgolla). The Wayamba Campus has a depas:tment of industrial management and computer studies.

The Sabaragamuwa University has a Faculty of Applied Sciences which consists of two departments, one of natural resources and the other of physical. sciences.

The Open University since its creation in 1980 has developed rapidly. It has three faculties of which. two are science based: the Faculty of Engineering Technology and the Faculty of Natural Science. The former has, apart from other usual departments, a department of agricultural and plantation engimeering and a department of textile technology. The Faculty of Natural Science conducts studies up to $\mathrm{Ph}$. D level.

\subsection{University Admissions.}

Students for universities (except the Open University) are selected by the UGC from results obtained at the General Certificate of Education (Advanced Level) Examination conducted annually by the Government Department of Examinations. The number admitted for physical sciences in 1995 (for academic year 1993/94) was 1809 which is $48.1 \%$ of the number eligible in that category. 'This is quite satisfactory when compared to $14.5 \%$ for all admissions. The academic year is backdated because the universities except Jaffna lost two academic years due to social disturbances in 1988-89. This gap is gradually narrowing. 


\subsection{MIDDLE LEVEL EDUCATION}

In Sri Lanka, the demand for tertiary and higher education has run ahead of the resources available. Therefore, it is essential to diversify the opportunities in the tertiary/higher education system. The enormous pressure on students seeking places in the conventional university system would be reduced if it would be possible to attract students to other avenues of tertiary education leading to middle level qualifications with an opportunity to take university degree programmes if so desired. Even though more job opportunities are available for personnel who obtain middle level qualification, the demand is less than that for traditional university education. By creating incentives in the form of (i) social recognition of the middle level qualification as a profession, (ii) opening avenues for those who later wish to obtain university degrees; it may be possible to popularise the middle level education and training.

\subsection{Technical Colleges}

Apart from the universities, physical science based courses are also conducted by technical colleges. These are directly administered by the Department of Technical Education and Training under the Ministry of Higher Education. The oldest is the Ceylon Technical College at Maradana established in 1893. Technical Coll.eges in Galle and Kandy were subsequently established in 1956.

The Hardy Institute of Techunology, Ampara named after its founding Director; Thumas Hardy was established in 1957.

The University of Moratuwa started as an Institute of Practical Technology. As stated earlier, it is now a well established university but it also still. conducts technical courses leading to the National Diploma in Technology. The course is of a high standard.

After the country received independence, there has been a fairly rapid increase in the number of technical colleges. The technical colleges may be roughly tabulated (Table 1) according to the period they were established.

Table 1: Establishment of Technical Colleges in Sri Lanka.

Period

$1890-99$

$1900-49$

$1950-59$

$1960-69$

$1970-79$

$1.980-89$

1990 -

Total

\section{Number of Technical Colleges}

01

00

04

05

09

09

04 
This shows that the country had only one technical college for over half a century and that after independence, technical colleges began to be established systematically. The thirty two technical colleges are distributed regionally throughout the island. They now have a total enrolment of 14791 , the annual admissions being around 12000 most of these being for short courses. These are of course among business study courses, general study courses and craft/ engineering courses. Courses last from three months to three years. Nearly all craft/engineering courses are full time. Craft/engineering courses include, among others, training to become jewellery manufacturers and designers, draughtsman apprentices, masons, automotive mechanics, electricians, gas and arc welders, general machinists, mechanical fitters, metal fabricators, plumbers, radio TV and electronics technicians, refrigerator and air conditioner mechanics, wood machinists, brass engravers and lathe machine tool operators.

\section{$2.2 \quad$ Other Training Programmes}

The technical and vocational education and training are handled by more than five Ministries including Labour and Vocational Training, Science Technology and Human Resources Development, Industries and Youth Affairs. Apart from the state sector, a large number of NGO operated institutions numbering over 2000 carry out vocational training programmes throughout the country.

\subsection{HIGHER EDUCATION BY OTHER ORGANISATIONS}

\section{$3.1 \quad$ Formal}

Almost all professional organisations are established to ensure that appropriate standards of practices of knowledge are developed within the professions. The students who have shown maturity, promise and potential but failed to enter the formal university system are given opportunities to pursue education at a higher level to acquire professional qualifications awarded by some professional. institutions. These programmes are conducted to suit those already employed. The professional bodies concerned with Architecture, Chemistry, Engineering, etc., play a leading role in this aspect in Sri Lanka. The courses conducted by these institutions not only provide an opportunity for non-university graduates to acquire professional qualifications but also for graduates to update their sliills and abilities in a particular discipline. This meets the demand for continuing professional education in the respective disciplines. The formal evaluation is also conducted by the institutions to test the theoretical basis of understanding of concepts especially in the application of the particular discipline. In a rapidly changing world, such as we live in today, it is imperative to cultivate and evolve elements of adaptability to change and to learn to adopt changes in the particular discipline. Formal courses conducted in disciplines such as architecture, chemistry, engineering, etc., are somewhat helpful to achieve the above objective. Since 
these courses are conducted only in English, they also indirectly contribute towards the achievement of Sri Lankan cohesiveness and ethnic harmouy. There is a need to decentralise these courses which now operate primarily in Colombo and its Suburbs. All formal courses are associated with rigid evaluation procedures leading to professional qualifications which are internationally recognised.

College of Education and Teachers Training Colleges, run by the Ministry of: Education should also be included in this category of formal professional institutions.

\subsection{Non-formal}

Continuing non-formal education assumes a vital role in the transformation of inclividual lives to more productive and fruitful types. The non formal education tends to begin at the end of the formal undergraduate, postgraduate or professional education. All types of formal education listed above, generally have gaps and voids especially with respect to the employment or the interests of persons receiving education. Many organisations in the professional. (NGO) sectors, the state sector, private sector and the educational sector conduct non-formal education in. the form of seminars, workshops, short term courses etc. All media agrencies also play an impontant role in this respect. There is always a lack of enthusiasm in the participation among many persons who are likely to benefit from such programmes. The encouragement by the employers in the form of some incentives will be a remedial measure.

\subsection{POSTGRADUATE EDUCATION AND RESEARCH IN PHYSICAL SCIENCES}

The impression that prevails among many graduates even today, is that the postgraduate education in science is not a reality in Sri Lanka. The general trend that existed in the last few decades and also exists today, is always to seek postgraduate education in science abroad. However it should be stated that postgracluate programmes were started quite early in Mathematics, Chemistry and Physics leading to the awards of M.Sc degrees to Mr P Kanagasabapathy (Mathematics) in 1946, Miss W.P.D. Peiris (Chemistry) and Miss. P. Kandasamy (Physics) in 1955. These achievements helped to eliminate the myth that prevailed on the necessity to go abroad to obtaim postgraduate degrees.

\subsection{Universities}

Universities of Sri Lanka were primarily established to conduct undergraduate science education by training students for the award of General Science and Special Science degrees in different subject combinations and subject areas. B.Sc. Special Courses are equivalent in some ways to M.Sc. courses. The tradition, 
which is modelled on old British Universities still persists with only some minor: changes. The research activities at Universities for postgraduate degrees in the past were mainly and understandably geared towards academic interest of individual teachers. Some dedicated university teachers were successful in creating an environment for research at universities, thus moving towards the achievement of excellence in the respective fields. However, in the recent past, there has been substantial diversification of research activities at Universities which better fulfills the needs of the country.

The only way to assess the output of research is to evaluate the research publications and communications including patonts during a particular period. Table 2 shows the output from different Universities during a five year period.

Table 2: Number of resear'ch publications and communications in physical sciences (1991-1996).

\section{University}

University of Colombo

University of Kelaniya

Open University

University of Peradeniya

Ruhuna University

Sri Jayewardenepura University

\section{Research output}

95
73
21
234
26
81

It should be said, that quantitywise, University of Peradeniya gains the first place. It is difficult to assess the quality of publications without referring to experts in the respective fields. Since the information in Table 2 does not carry the distinction between publications and communications, the assessment on the quality is more difficult. Still this reveals a substantial development of research at University of Peradeniya in the last few decades which has led to the estab]ishment of a Postgraduate Institute of Science there in 1997.

In addition to the publications, the number of postgraduate degrees awarded also gives an assessment of the Postgraduate research. It is obvious that the number of postgraduate degrees awarded is relatively small in comparison with the research programmes. A postgraduate degree (M.Phil or Ph.D.) generally takes more time than expected mainly due to lack of facilities including the accessibility to recent literature. Another contributory factor is that the supervisor is often required to assist the undergraduate teaching programmes and / or administration as the prime duty which limits a person's devotion of time for guiding research. Further, the non existence of research groups at many institutions could contribute to these delays. In many developed countries, the research student is also guided by the research group even if the supervisor is tor) busy with other activities. The existence of a research group (team) is a rare 
occurrence in Sri Lanka. There is always a necessity to encourage team work in research in Sri Lanka by providing adequate facilities and environment for research. The NSF (NARESA) often makes grants to University staff to help them to form teams in their selected field to conduct research. The establishment of such groups will undoubtedly reduce the undue delays in the submission of theses for postgraduate research degrees. Very often there is an undue delay between the submission of the thesis and the award of the degree. The procedure for the award of a postgraduate degree is often not as smooth as that of the B.Sc. degree. The Postgraduate Institute of Science (PGIS) at the University of Peradeniya may be a remedial measure to overcome such difficulties. This necessitates the gradual release of University staff from heavy undergraduate teaching and evaluation work, giving more incentives for the initiation of more and more research activities.

Obtaining a Ph.D degree in Physics locally was long considered to be a difficult task due to many limitations. However through a Sandwich postgraduate programme, some Sri Lankan Universities were able to produce Ph.Ds in physics from about 1.991. This has been possible through the active support of the International Science Programmes of the Uppsala University, Sweden.

Coll aborative research programmes with foreign universities and foreign clonors have assisted in the development of postgraduate research in our universities and research institutions.

\subsection{Other Research Institutions}

Apart from Universities, the research institutions in Sri Lanka have a vital role to play. The applied and basic research that these institutions are expected to carry out, should as far as possible be geared towards the award of a postgraduate degree by a University. This enhances the quality of the applied research and also helps to incorporate fundamental principles of the subject area to interpret the results, thus achieving a proper guidance of the "Applied research". For example, the monitoring programme for the collection of baseline data on the enviromment could be oriented towards the meaningful interpretation of the data and investigation on improvements of the techniques etc. Since the presentation of only the data in a thesis is insufficient for the award of a postgraduate degree, the researcher(s) will pay more emphasis on the interpretation and improvement of techniques, if the award of a postgraduate degree is anticipated in association with the work. This enables the researcher(s) to produce not only a mere set of data but also a meaningful interpretation which in the long run helps in the development of the country. The applied research associated with an award of a postgraduate degree is always properly guided by the fundamental principles in the subject area, which prevents the repetition of similar type of work at another institution. The applied research based on the same fundamental principle is often conducted at two different institutions claiming that the iesearch work is a requirement 
of the institution. A careful study on the fundamental principle of the applied research very often reveals that it is repetition of the work conducted by another institution. The unnecessary expenditure involved on such researeh can be mitigated if the work is associated with the award of a postgraduate degree, which gives more incentives for the researcher(s) to look for correlation with fundamental puinciples. There is always a need for encouraging all research actuvities whether applied or basic by ensuring that they lesal to the award of postgraduate degrees. The NSF (NARESA) has often helped with frants to researchers in institutions to work in their laboratorics with students registered for posturaduate degrees at Univer'sities.

\subsection{Postgraduate courses in Physical Sciences}

Juring the last two decades there has beev a considerable rrowth in the number of jostgraduate courses offered by Universities (Table 3).

Table 3: Postgraduate courses in physical sciences offered by Universitics.

University Postgraduate course Year of commencement Intake

Colombo M.Se. in

$\begin{array}{lll}\text { i. Analytical Chemistry } & 1975 & 75 \\ \text { ii. Nuclear Science } & 1990 & 12 \\ \text { iii.Computer Science } & 1990 & 50 \\ \text { i\&. Applied Statistics } & 1977 & 25\end{array}$

Postgraduate Diploma in

v. Applied Statistics $\quad 1977$

vi. Chemical Analysis $\quad 190 \overline{5} \quad 20$

Peradeniya M.Se. in

i. Analytical Chemistry $\quad 1997$

ii. Industrial Chemistry $\quad 1997 \quad 20$

iii. Medical Physics $\quad 1996 \quad 10$

iv. Gcmmology $\quad 199620$

Sri Jayewardenapura M.Sc. in

i. Polymer Science and Technology $1977 \quad 10$

ii. Industrial mathematics $\quad 1946 \quad 20$

iii Statistics $\quad 1977$

Postgraduate Diploma in

iv Statistics 
The structures of the postgraduate courses listed in 'lable 3 are more or less similar. All courses consist of lectures and practicaliastignments of apprixi mately one year duration followed by a research project which is not stlituly akscised as for a M. Phil(research) degree. Most of these courses provide opportunitics tor in-service training facilities to employed graduates wh wish tir enhance? thein knowledgo/ski]l. Since the lectures and practical chasser are condached atter working lours and on Saturdays/Sundays, the compleyed sraduates could follow the courses without affecting their mployment. Very often the course [iestare pitis by the employers. Since the course contents best direct rulevance to industrial neds, it coutd be satid that these courses provide for mimpower

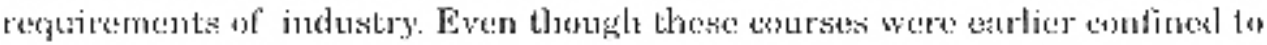

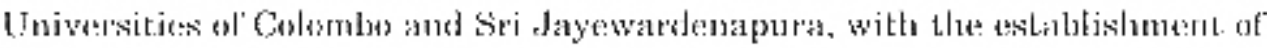

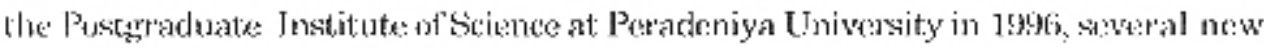
courses commenced. (Table 3 )

'There is an jnereasing trend for the commencement of pestgraduate

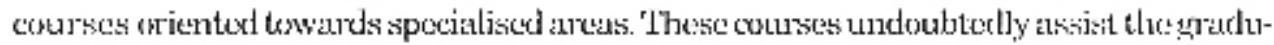
atces to enhanee their knowledgo/sdill relevent to their employment. 'Lalsle 4 shows proposed postgraduate courses at difterent Universities.

\section{Table 4 : P'roposed P'ostgraduate Courses.}

\section{University}

Corlomber

Kelaniya

Putadeniya

\section{Postgraduate Course}
i. M.Se, in Almospheric Physics
ii. M.Sc. in Medical Physias/Radiobiology

i. M.Sc. in Industrial and Environmental Chemistry

ie. Posturaduate Diploma in Lilectronics

iii. M.Sis. in Industrial Banagement.

iv. M.Sc. in Gomputer Science:
i. M.Se, in I'bysics of' Materials
ii. M.Se. in Science Eductation
iii M.Se in Industrial Matherratics
iv. M.Se in Applied Stálistici

'lhe rescarch component: of these M.Sce cotrses could always be directed towards the development of industry. Since the projects are clesely momitored or supervised by University personel, it would be possible to impart a clear vision on the researcher of the fundamental principles of the pregiect behind the

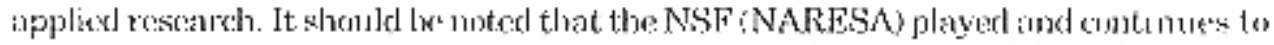
play an important role in providing funds and other facilitics for efficient execution of many postigraduate roseturet programmes. 


\subsection{OBSEILVATIONS}

Since the 1960 s, there has been a rapid increase in the number of highter educitional institutions in Sri Lanka along with a similar incrense in the numbers undereroiens tertial'y etucation. It should be enuphasized that the quatity of the finkt procluct should in to way be allowed to decrease with the increase of numbers. 'l'he content of the physical science courses therefore need to be continually updated to meet the atemands of the developing world and the country. This should especially unsider establishing altser links in science restarch hetween the universities and indestries.

Ii has been noted by the Commission of lnctury on Texhnical Edusation which inquired into the dewelopment nexsds of the exuntry that while there has been a ripid increase in numbess gualified at university level and manual werkers, there: are insulficient number's of midelle grade cadre. Although these hits been a gretdual increase in the number of technical colleges to alleviate this problem, the: situntion still needs further attention. Universities and reseenel institute!s aced to be encouraged to do more research relevant to the country's comomic developnent, withrut noglecting hasic research. More funds neet to be made available for such work. Physical sciences in the unirersitios can then louk [orward to it briçht and encouragring fulure.

\section{Reterences}

1. Linives'sity of Sri Lanka, Handbook (1983)

2. Sri Lả kán Universities, Year Book (1996)

i. Statistical Hand Book on University Education (1995)

4. Report on the Scientific and Technical Persomel Development Project (1957)

5. 'Tenth Annual Technical Session of the Orgennization of Fral'ussionial Associátions (1997)

6. Reprort of che Commission of Inquiry on Technical Education (1963) 